\title{
Consumer Behavioral Systems to Approach or Avoid Generic Medicine (GM) Consumption in Japan
}

\author{
Takefumi Hosoda ${ }^{1}$, Jay R. Fraser ${ }^{2}$, Myung-Sook Kim ${ }^{3}$, Hongsik John Cheon ${ }^{4}$
}

Received: April 12, 2018. Revised: April 24, 2018. Accepted: May 5, 2018.

\begin{abstract}
Generic medicine (GM), which is an alternative drug product for branded medicine (BM), is used less in Japan than in other OECD countries. Therefore, we investigate why the medical consumers of Japan avoid the use of GMs even though the efficacy and safety of the medicines have already been proven. We theorize that effectiveness or risk of GMs are related to the consumer attitude toward GMs is affected by the behavioral approach/activation system (BAS) which promotes actions to reach the desired state, and the behavioral inhibition system (BIS) which suppresses behaviors to avoid negative outcomes. To see which of the BAS and BIS dimensions are related to GM usage, we surveyed 374 Japanese consumers and found that Quality, Efficacy, Safety, \& Cost-effectiveness with the BAS, and Functional Risk, Financial Risk, Social Risk, Physical Risk, Psychological Risk, \& Time Risk with the BIS had a significant effect on consumer attitude to GMs. These results are important in that they 1), confirm the role of BAS/BIS in attitudes to GMs, 2), provide guidelines when marketing GMs, 3), help governments promote the use of GMs as a cost-saving measure, and 4), guide future surveys regarding consumer attitudes to GMs.
\end{abstract}

Keywords: Generic Medicine, Branded Medicine, BIS, BAS, Second-order Factor Analysis.

JEL Classification Code: I15, M16, Z18.

\section{Introduction}

Generic medicine (GM), an alternative drug product for branded medicine (BM), is a pharmaceutical that contains duplicates of the ingredients from the original, patentexpired BM, and therefore, it offers the same or improved effects (Dylst, Vulto, \& Simoens, 2012). Consumers can purchase GMs at a lower price since the manufacturer is not required to undertake clinical tests or validate its efficacy and safety, as these have already been proved by the BM manufacturer (Gonzalez, Sismeiro, Dutta, \& Stern, 2008;

1 First Author. New Product Planning Manager Takeda Pharmaceutical Company Tokyo, Japan [Postal Address: 12-10, Nihonbashi 2chome, Chuo-ku Tokyo 103-8668]

E-mail: takefumi.hosoda@takeda.com

2 College of Business, Soongsil University, Seoul, Korea. E-mail: jayrfraser@gmail.com

3 College of Business, Soongsil University, Seoul, Korea. E-mail: ms7785200@naver.com

4 Corresponding Author. College of Business, Soongsil University [Postal Address: 369 Sangdo-Ro, Dongjak-Gu, Seoul, Korea].

E-mail: hcheon@ssu.ac.kr
"OECD Health Statistics 2016 Definitions, Sources and Methods," 2016). The use of GM is considered a promising idea for an alternative medical cost-saving plan of the Japanese Government, as the government pays $70 \%$ of the medical care of its population, and the highest elderly population among the Organisation for Economic Cooperation and Development (OECD) countries is in Japan(Ikegami et al., 2011; OECD, 2017a). The rate of the GM market share in Japan, however, has stalled at $12 \%$, which is much lower than the average of $25 \%$ that exists among the other OECD countries(OECD, 2017b). While the market conditions in Japan were different from other OECD countries in the past, for example, pharmacists were not allowed to substitute prescription drugs for generic drugs until 2012, from 2007 the Japanese Ministry of Health, Labour, and Welfare has been promoting the use of GMs with an increased effort in 2012 with the use of policy tools such as financial incentives for pharmacists, patients and medical institutes which are similar to other OECD countries (Kuribayashi, Matsuhama, \& Mikami, 2015; MHLW, 2012; OECD, 2017). The following question then remains: Why do the medical consumers of Japan avoid the use of GMs even though the efficacy and safety of the medicines have already been proven 
It is argued that factors such as functionality, safety, and economics exert major effects on the consumer preference regarding the purchasing of drug products (Bearden \& Mason, 1978). For the present study, the factors that influence consumers in their GM-purchasing decisions were selected, and then two Gray-theory-based consumer psychological behavioral systems were utilized, as follows (Lambert, Doering, Goldstein, \& McCmormick, 1980). The behavioral approach/activation system (BAS) which promotes actions to reach the desired state, and the behavioral inhibition system (BIS) that continually suppresses behaviors to avoid negative outcomes (Erdle \& Rushton, 2010; Gable et al., 2000; Lambert et al., 1980; Tootelian et al., 1988). To establish the research hypothesis, the BAS and the BIS were considered as the determinants of the consumers' motivations regarding their GM choices. This means that risk-taking can underpin the patient decisions regarding the consumption of GMs, where a partial reason such as a lower price is not only influential, but functionality, safety, and belief are also considerations. To examine the consumer behavior regarding GMs, Quality, Efficacy, Safety, and Cost-effectiveness were selected as the BAS factors, and Functional risk, Financial risk, Social risk, Physical risk, Psychological risk, and Time risk were selected as the BIS factors (Kim \& Kim, 2017). A fragmented explanation for the consumer behavioral system that was categorized according to the BAS-BIS framework was formulated through a validation for which multi-order confirmatory factor analyses (CFAs) and structural-equation models were used.

\section{Choosing GMs}

In the extant literature on the consumer behaviors towards GMs, it is claimed that consumers rely on generic prescriptions or alternatives to save money (Bearden \& Mason, 1978). In the early 1980s, many researchers continued to study GMs, leading to the discovery that the efficacy, potential financial gain or loss, and safety affect the consumer decisions. Specifically, the age of the consumers and the drug efficacy are two important factors affecting GM purchases (Lambert et al., 1980). The critical factor for consumers in the case of a high BM preference is the drug efficacy(Tootelian et al., 1988). However, when consumers intend to purchase a GM, the quality, safety, and effectiveness are critical factors (Kim, Kim, \& Kim, 2011; Shepherd, 1988). When consumers recognize that a GM is the same as the BM version, they are much more confident in using the GM if it has been recommended by doctors or pharmacists (Ghassemzadeh, Hojabri, Eftekhar, \& Moslem,
2013; Podulka, Krautkramer, Amerson, Phillips, \& Dolinsky, 1989). More than $90 \%$ of consumers in the GM study on recognition and behavior perceive GMs as lower in price than BMs, while only $10 \%$ anticipate more side-effects from the GM compared with the BM. Especially, patients prescribed a BM for chronic diseases were more likely to switch to a GM than those who were prescribed a GM to switch to a BM (Kim \& Kim, 2017; Shrank et al., 2006). This finding indicates the realization of numerous consumers regarding the efficacy and utility of GMs. Still, the opinions of people who are less educated or elderly impact on the negotiation of GMs. Thus, the focus should be the delivery of GM education to people who are disadvantaged, elderly, or who suffer from chronic diseases (Chong et al., 2011).

Despite a steady reduction in the chronic-disease rate in Japan, both the absolute numbers of those with chronic medical conditions and health expenditures, both in absolute terms and as a portion of social expenditures will continue to increase as the elderly population increases (Ishii, Ogawa, \& Akishita, 2015; The Aging Society: Current Situation and Implementation Measures, 2015). To solve this problem, all of the related departments or authorities and health organizations must establish financial-aid programs as laid out by the health-policy plans of Japan (Yach, Hawkes, Gould, \& Hofman, 2004). The role of GMs becomes more significant as the high cost of BMs exerts a burden on everyone including health authorities and patients. Therefore, the consumer recognition regarding the economic benefits and the equivalent quality that GMs provide is the first step of a financial solution. When GM sales increase in a market, it is anticipated that the BM prices will fall. The data, however, show that the BM prices of Japan have only reduced by $15.6 \%$, equivalent to $11 \%$ of the GM market share and this is not significant (Rizzo \& Zeckhauser, 2009). Currently, GM sales are increasing slowly, and the Japan Government is seeking out ideas to increase GM usage among the national health authorities (Jakovljevic, Nakazono, \& Ogura, 2014). For instance, the GM prices of Japan are reduced annually by $5 \%$ through the utilization of the market price analysis, which is supported by the Official Price Reimbursement System (Choi \& Choi, 2009). Accordingly, as the GM market grows, the BM market price has decreased, thereby stabilizing the medical costs over the long term.

\section{BAS and BIS Consumer Decision-making}

\subsection{BAS \& BIS}

The consumer evaluation criteria regarding the effectiveness or risk of GMs are related to the consumer 
attitude toward GMs (Bearden \& Mason, 1978; Kim, Cha, \& Park, 2017; Peter \& Tarpey, 1975). The BAS and BIS are the two dimensions that were developed in the formulation of the reinforcement sensitivity theory, where they were classified as the components of the human motive system (Gray, 1976). This theory argues that, to achieve their ideal state, humans derive their personality and preferences from their biological features such as the brain system. It is important to note that the BAS is referred to by other terms including behavioral approach system,(Davidson, 1993; Gray, 1981) behavioral engagement system,(Depue, Krauss \& Spoont, 1987) and behavioral facilitation system (Depue \& lacono, 1989). The BAS is comparable to the psychological acceleration system that leads an organism to what it desires that is, the system senses taste, sex, or avoidance of pain to acquire what is most desirable. Further, in anticipation of the attainment of the most desirable option, it initiates feelings of hope, excitement, and happiness(Kim, 2018). The BIS, however, is comparable to the psychological brake system of an organism for the avoidance of punishment or dangerous conditions. When a human anticipates the unfavorable results that generally come with feelings like fear, frustration, anxiety, and sadness, and a high BIS sensitivity is strictly correlated with these feelings. Research has shown that college students with a high BIS score tended to react sensitively to the punishments and experienced higher anxiety levels (Carver \& White, 1994).

If the BAS and BIS exert control over human behaviors, then it is important to understand the way that these systemic differentials affect the manner in which people respond to GMs in terms of their personal welfare and health. For instance, the BAS sensitivity determines the way that a person will react to an anticipated reward, while the BIS sensitivity measures the way that a person reacts to an imminent danger or punishment. A high BAS sensitivity triggers extreme reactions to reward cues, while a low BIS sensitivity leads to a lack of behavioral control, even with the prospect of punishment, thereby causing the Attention Deficit Hyperactivity Disorder (ADHD). Furthermore, an extremely high BIS sensitivity causes anxiety disorders (Quay, 1988, 1993). A consumer with a high BIS level is likely to be concerned about the risks from the choosing of a GM that manifests in a demonstration of anxiety at the moment of purchase alternatively, a consumer with a high BAS level would think about the advantage of the GM selection and would also feel satisfied from using it after it is purchased. In short, two different consumers with such converse tendencies would have different degrees of the purchase intention.

\subsection{Approach Behavior}

The main point of the GM choice is the reasonable price, or its cost-effectiveness. Specifically, in an economy with high prices, price is the most concerning issue, which is also an important factor in the research on successful strategies regarding GM selling (Kim, 2013). The governments of Norway and France seek to guarantee profits for pharmacists when they recommend the GM alternative over the BM version. In Norway, pharmacists must inform a patient about the available GM, and they would naturally encourage patients to use the GM option to gain higher profits (Brekke, Holmås, \& Straume, 2010). Since 1999, unless it is stated otherwise by a doctor, pharmacists in France are allowed to substitute a BM with a GM, but they must inform the patient of the substitution, and it is the right of the patient to refuse the GM. In 2006, the French Government targeted the GM-usage rate of $70 \%$, cutting GM-drug prices by $10.74 \%$, while the BM prices were only reduced by $2.5 \%$, and this was implemented to incentivize consumers through financial motivation. In The Netherlands, pharmacists are provided with one third of the GM-BM price difference as profit (Simoens \& De Coster, 2006). In Austria, the drug-selling profit rate is set differently according to the drug price, as follows: $27 \%$ profit for 10 euros or less, and $3.8 \%$ profit for drugs costing $€ 357.8$ or more.

A consumer or a patient can use the following two values to recognize quality: cue predictive value and cue confidence value (Olson \& Jacoby, 1972). To obtain the expected value, a certain cue is mapped on the product's quality, and this provides reliability in the solving of problems. The confidence value is the certainty of a consumer's ability to use the cue to evaluate a product. These judgments play significant roles in the evaluation process (Prashar, Raja, Parasaran, \& Venna, 2015). The negative point of using GMs is that consumers generally perceive its quality as lower than that of the BM(Richardson, Dick, \& Jain, 1994), and this is because GMs are designed to compete with BMs on price however, consumers perceive the lower price as an indicator of lower quality. Notably, however, the GM sales in Europe were recently boosted by a change of consumer thinking, as the quality of GMs became known as reliable throughout the world. Accordingly, Belgium, Spain, the U.K., Italy, and Portugal initiated advertising that presented the quality and efficacy of GMs and BMs as the same. In Portugal, a pro-GM advertising campaign targeted patients, doctors, and pharmacists and GM sales increased as a result. Since 2003, GM publicservice announcements have been broadcast in France, and advertising has encouraged chronic-disease patients and BM consumers to switch to GMs; consequently, 
approximately $50 \%$ of patients started using GMs. In January 2006, the national health insurance of the French Government and the country's pharmacists confirmed the aim of the replacement of $70 \%$ of the 20 top-priced BMs with the corresponding GMs by the end of 2006 (Bae, Lim, \& Bae, 2009).

The approval for the sale of a GM is based on the following conditions: Six years of efficacy and safety testing (FDA Fact Sheet: What's Involved in Reviewing and Approving Generic Drug Applications?, 2017) and the submission of data from a bioequivalence or clinical test that show that a comparison with the original BM has been completed. Generally, these criteria are not common knowledge among most patients or consumers (Shin \& Choi, 2008). Sweeney and Soutar (2001) claimed that consumers are able to make better decisions when they consider multiple factors rather than just a single factor (Sweeny \& Soutar, 2001). In terms of GM policy, this claim could be derived from the idea that the efficacy levels of GMs compared with those of the original drugs are almost identical, as has been proven by the equivalent clinical tests (Ganther-Urmie et al., 2004). Therefore, an examination of the following four consumer behavioral factors that are relevant to the GM-selection process was conducted (see Table 1): Quality, Efficacy, Safety, and Cost-effectiveness (or Price).

\subsection{Avoidance Behavior}

The avoidance behavior that consumers show regarding GMs stems from the perceived risk that is derived from the following two factors: uncertainty and loss (Jacoby \& Kaplan 1972; Shrank, Cox, Fischer, Mehta, \& Choudhry, 2009; Vincent \& Zikmund, 1976). The belief of many researchers is that the perceived risk is the expected loss that is a consequence of the purchase, rather than a perceived uncertainty therefore, a delay or cancellation of the purchase occurs (Peter \& Ryan, 1976; Peter \& Tarpey, 1975). Others have also suggested that, rather than considering the perceived risk as an expected value like uncertainty or a consequential function, it should be defined and developed as the expected loss that is an independent component(Stone \& Winter, 1987) and can be defined as the overall uncertainty (Kassarjian \& Robertson, 1991; Stone \& Gronhaug, 1993). Thus, the perceived risk affects a consumer's decision making and can be defined as the expected loss from the purchase, which is an inhibiting behavior regarding the purchase (Peter \& Ryan, 1976). Numerous factors affect the perception of a single risk. The probability of each factor is independent, and they are independently cumulative when it is expected that one or more losses will occur (Bettman, 1975; Peter \& Tarpey, 1975).

Jacoby and Kaplan (1972) and Brooker (1984) classified this risk into the following five types: financial, functional, physical, social, and psychological (Brooker, 1984; Jacoby \& Kaplan, 1972), moreover, Peter and Ryan (1976) added time/comfort loss (Peter \& Ryan, 1976) and Zikmund and Scott (1977) then added opportunity loss (Zikmund \& Scott, 1977). Stone and Gronhaug (1993), however, divided risk into the following two categories: financial/functional/ physical/time risk and social/psychological risk (Stone \& Gronhaug, 1993). Next, Schiffman and Kanuk (1994) divided the perceived risk into the groups of financial, safety, functional, social, psychological, and time loss (Schiffman \& Kanuk, 1994). Kurtz and Clow (1997) later classified the risk into three types, as follows: social/psychological, financial, and consequential (Clow, Kurtz, Ozment, \& Ong, 1997). Perceived risk has been categorized differently by different analysts, but the following six types of risk are categorized for the present study: Financial, Functional, Physical, Psychological, Social, and Time Loss (see Table 2).

Accordingly, the concepts and subordinate factors of the BAS and BIS were combined in reference to the preceding research, leading to an attainment of the specific behaviors and characters that are shown by consumers toward GMs. Further, an examination of whether the following four secondary dimensions, Quality, Efficacy, Safety, and Costeffectiveness, converge to the BAS needs to be performed. Likewise, the BIS comprises six risks that have been established using the basic theories and previous studies, the secondary dimensions, as follows: Functional Risk, Financial Risk, Social Risk, Physical Risk, Psychological Risk, and Time Risk. As Table 1 and Table 2 show in greater detail, a variety of studies provided the measurement items for the determination of the BAS and the BIS, respectively. 
Table 1. Behavioral activation system (BAS) of generic medicine

\begin{tabular}{|c|c|c|}
\hline \multicolumn{3}{|c|}{ Behavioral Activation System (BAS) } \\
\hline Dimensions & Existing Support & Items \\
\hline Quality & $\begin{array}{l}\text { A drug will be uniformly effective in performance(Mason \& } \\
\text { Bearden, 1980). } \\
\text { Similar to the savings benefit, the quality benefit boils down } \\
\text { to increasing value for money, but unlike the former, it } \\
\text { usually involves spending more money(Blattberg \& } \\
\text { Wisniewski, 1989; Chandon, Wansink, \& Laurent, 2000; } \\
\text { Narasimhan, 1984). }\end{array}$ & $\begin{array}{l}\text { 1. GM has consistent quality. } \\
\text { 2. GM includes the same active compound of brand. } \\
\text { 3. Additives are the same in GM and BM }\end{array}$ \\
\hline Efficacy & $\begin{array}{l}\text { No significant differences were found among the three } \\
\text { samples regarding their views of the efficacy(Mason \& } \\
\text { Bearden, 1980). }\end{array}$ & $\begin{array}{l}\text { 1. The efficacy of GM is the same as BM } \\
\text { 2. GM takes longer time to be efficacious. } \\
\text { 3. GM is as potent as brand medicine. } \\
\text { 4. GM (prescribing) generally leads to use of drugs } \\
\text { which will produce the intended therapeutic results. }\end{array}$ \\
\hline Safety & $\begin{array}{l}\text { The FDA believes no significant quality differences exist } \\
\text { between generic and brand name drugs and contends that } \\
\text { most differences are largely semantic(Mason \& Bearden, } \\
\text { 1980). }\end{array}$ & $\begin{array}{l}\text { 1. GM may be safe for me and my family. } \\
\text { 2. GM is something that I feel safety about using. } \\
\text { 3. GM is just as safe as brand name drugs. } \\
\text { 4. GM has no problems of safety. }\end{array}$ \\
\hline $\begin{array}{l}\text { Cost } \\
\text { Effectiveness }\end{array}$ & $\begin{array}{l}\text { Sales promotions can provide perceptions of monetary } \\
\text { savings by lowering the unit price of the promoted product, } \\
\text { offering more of the same product for free, or providing } \\
\text { refunds or rebates on subsequent purchases of the same or } \\
\text { other products. Both the size of the price reduction and the } \\
\text { deviation from a reference price can create perceptions of } \\
\text { monetary savings and can reduce the pain of paying } \\
\text { (Blattberg \& Wisniewski, 1989; Chandon et al., 2000). }\end{array}$ & $\begin{array}{l}\text { 1. GM is reasonably priced. } \\
\text { 2. GM is a good product for the price. } \\
\text { 3. GM would be economical. } \\
\text { 4. Overall, I am happy with the price of GM. } \\
\text { 5. GM can save money when I purchase prescriptions. } \\
\text { 6. GM are less expensive than BM. }\end{array}$ \\
\hline
\end{tabular}

Table 2: Behavioral inhibition system (BIS) of generic medicine

\begin{tabular}{|c|c|c|}
\hline \multicolumn{3}{|c|}{ Behavioral Inhibition System (BIS) } \\
\hline Dimensions & Existing Support & Items \\
\hline $\begin{array}{l}\text { Functional } \\
\text { Risk }\end{array}$ & $\begin{array}{l}\text { Consumers doubt the Quality of GM. } \\
\text { (Bearden \& Mason, 1978; Mieres, Martín, \& } \\
\text { Gutiérrez, 2006). }\end{array}$ & $\begin{array}{l}\text { 1. I am suspicious of the quality of GM } \\
\text { 2. I am afraid that GM's efficiency may not be sufficient. } \\
\text { 3. I am afraid that GM may not leave your health in good condition. } \\
\text { 4. I am suspicious of the ingredients used in GM's manufacturing. } \\
\text { 5. I think that GM is not going to give you good efficacy. }\end{array}$ \\
\hline $\begin{array}{l}\text { Financial } \\
\text { Risk }\end{array}$ & $\begin{array}{l}\text { Consumers think buying the } \mathrm{GM} \text { is not } \\
\text { worthy(Bearden \& Mason, 1978; Mieres et } \\
\text { al., 2006). }\end{array}$ & $\begin{array}{l}\text { 1. I think that buying GM is a waste of money. } \\
\text { 2. I am worried that GM is not worth the money. } \\
\text { 3. It is not a wise way of spending money. }\end{array}$ \\
\hline Social Risk & $\begin{array}{l}\text { If consumers buy and take GM, others will } \\
\text { have a negative viewpoint(Bearden \& } \\
\text { Mason, 1978; Mieres et al., 2006). }\end{array}$ & $\begin{array}{l}\text { 1. I am worried that if I buy GM, the esteem my family or friends } \\
\text { have for me may drop. } \\
\text { 2. I am afraid that if I buy GM, it may negatively affect what others } \\
\text { think of me. } \\
\text { 3. I think that if I buy GM, others will not see me the way I want them } \\
\text { to. } \\
\text { 4. I am afraid that if I buy GM, others may look down on me. }\end{array}$ \\
\hline
\end{tabular}




\begin{tabular}{|c|c|c|}
\hline Physical Risk & $\begin{array}{l}\text { Consumers worry about the side effects or } \\
\text { negative results of GM to their family or } \\
\text { themselves(Bearden \& Mason, 1978; Mieres } \\
\text { et al., 2006). }\end{array}$ & $\begin{array}{l}\text { 1. I am afraid that GM may not be safe for me or my family. } \\
\text { 2. I am afraid that GM may damage my health. } \\
\text { 3. I think that GM may cause you some physical harm. } \\
\text { 4. I consider that generic medicine may be dangerous for me or } \\
\text { some member of my family. }\end{array}$ \\
\hline $\begin{array}{l}\text { Psychological } \\
\text { Risk }\end{array}$ & $\begin{array}{l}\text { Consumers feel uncomfortable with buying } \\
\text { and taking GM(Bearden \& Mason, 1978; } \\
\text { Mieres et al., 2006). }\end{array}$ & $\begin{array}{l}\text { 1. Buying GM will make me feel uncomfortable with myself } \\
\text { 2. Buying GM does not fit in well with the concept I have of myself } \\
\text { 3. It makes I doubt whether I was right in buying GM }\end{array}$ \\
\hline Time Risk & $\begin{array}{l}\text { Consumers might waste their time because } \\
\text { they buy and take GM(Bearden \& Mason, } \\
\text { 1978; Mieres et al., 2006). }\end{array}$ & $\begin{array}{l}\text { 1. I am afraid that buying GM may be a waste of time due to its bad } \\
\text { result. } \\
\text { 2. I am afraid that buying GM will be a waste of time if I have to } \\
\text { change it for another BM. } \\
\text { 3. I am afraid that I may waste time with possible complaints as a } \\
\text { consequence of buying GM. } \\
\text { 4. I consider that buying GM may be a nuisance due to wasted time } \\
\text { as a consequence of buying something that may be worthless. }\end{array}$ \\
\hline
\end{tabular}

\section{Results}

\subsection{Sample}

Churchill's (1979) scale-development paradigm was followed to measure and validate the consumer behavioral systems that have been derived from the extant literature (Table 1 \& Table 2) (Churchill, 1979). To develop and purify a scale of the consumer behavioral systems for which the items in Table 1 and Table 2 are used, a national sample of 374 Japanese consumers (177 men and 197 women) from June and July 2015 was employed. The numbers of respondents who were aged in their $20 \mathrm{~s}, 30 \mathrm{~s}, 40 \mathrm{~s}, 50 \mathrm{~s}, 60 \mathrm{~s}$, and over at the time of the data collection are 53(14.2\%), 92(24.5\%), 98(26.3\%), 90(24.1\%), and 41(10.9\%), respectively.

\subsection{Exploratory Factor Analysis}

Before the evaluation of the goodness-of-fit test for the model, the exploratory factor analysis (EFA) was implemented through a reliability analysis to study the concepts of the single-dimension variables. The KaiserMeyer-Olkin (KMO) Test $(=.72)$ and the Barlett's Test $\left(\chi_{1431}^{2}=5198.34, p<.01\right)$ were carried out to confirm the validity and adequacy of the items in the measurement of the secondary factors of the BAS and BIS. To examine the independence of the 10 dimensions of the two primary dimensions, and to identify the variable structures, a primary component analysis was conducted per dimension through an implementation of the Varimax rotation. Using the corresponding results, an eigen value of 1 or more was used for all of the 10 factors (Kaiser, 1960). The items with a factor coefficient of .40 or less and the items with overlapped factor coefficients were eliminated.

\subsection{Measurement \& Validation of the Behavioral Systems}

The confirmatory factor analysis (CFA) was performed to examine the convergent validity and the discriminant validity of the items since it is likely that the other types of validity, such as the facial or nomological types, have been measured and confirmed in previous studies (Anderson \& Gerbing, 1988).Thus, post hoc measurements and the implications of the data that have already been examined by other studies were utilized, and the development of these that is based on the CFAs of this study is regarding those two validities. Further, a second-order CFA was carried out. As predicted, the 10 dimensions (e.g., four dimensions of the BAS construction and six dimensions of the BIS construction) are not orthogonal. To test the BAS and BIS higher-order structures of these 10 factors, an estimation of the model was performed using the two second-order factors, and a comparison was made with the model of one of the second-order factors (Bollen, 1989). Each latent variable comprises the following observed variables: 17 indicators for the six BAS interactive dimensions and 23 indicators for the four BIS interactive dimensions. The BIS and BAS results from the second-order CFA are as follows (Table 3 \& Figure 1). 
Table 3. Second order confirmatory factor analysis of the BIS \& BAS

\begin{tabular}{|c|c|c|c|c|}
\hline Latent Variables & $\begin{array}{l}\text { Observed } \\
\text { Variables of } \\
\text { Items }\end{array}$ & $\begin{array}{c}\text { Estimated } \\
\text { Value }\end{array}$ & SE & t-value \\
\hline \multirow{3}{*}{ Quality } & Q 1 & 1.00 & .07 & $15.23^{\star \star}$ \\
\hline & Q 2 & 1.23 & .07 & $18.87^{\star *}$ \\
\hline & Q 3 & 1.06 & .07 & $15.33^{\star \star}$ \\
\hline \multirow{4}{*}{ Efficacy } & E 1 & 1.28 & .06 & $19.80^{\star \star}$ \\
\hline & E 2 & 1.26 & .06 & $22.71^{\star \star}$ \\
\hline & E 3 & 1.30 & .06 & $23.27^{\star \star}$ \\
\hline & E 4 & 1.01 & .06 & $17.62^{\star \star}$ \\
\hline \multirow{4}{*}{ Safety } & S 1 & 1.21 & .05 & $22.51^{\star \star}$ \\
\hline & S 2 & 1.19 & .05 & $22.07^{\star \star}$ \\
\hline & S 3 & 1.07 & .06 & $18.24^{\star \star}$ \\
\hline & S 4 & 1.17 & .05 & $21.54^{\star \star}$ \\
\hline \multirow{6}{*}{ Cost Effectiveness } & CE 1 & 1.22 & .05 & $23.71^{\star \star}$ \\
\hline & CE 2 & 1.25 & .05 & $24.42^{\star *}$ \\
\hline & CE 3 & 1.24 & .05 & $24.82^{\star \star}$ \\
\hline & C E 4 & 1.10 & .06 & $18.44^{\star \star}$ \\
\hline & CE 5 & 1.15 & .06 & $20.75^{\star \star}$ \\
\hline & CE 6 & 1.09 & .06 & $18.47^{* *}$ \\
\hline \multirow{5}{*}{ Functional Risk } & Fu R 1 & 1.24 & .06 & $22.46^{\star \star}$ \\
\hline & Fu R 2 & 1.18 & .06 & $21.16^{\star *}$ \\
\hline & Fu R 3 & 1.17 & .05 & $22.65^{\star \star}$ \\
\hline & Fu R 4 & 1.26 & .05 & $23.58^{\star *}$ \\
\hline & Fu R 5 & 1.29 & .05 & $23.69^{\star *}$ \\
\hline \multirow{3}{*}{ Financial Risk } & Fi R 1 & 1.04 & .05 & $19.65^{\star \star}$ \\
\hline & Fi R 2 & 1.20 & .05 & $22.89^{\star \star}$ \\
\hline & $\mathrm{FiR} 3$ & 1.32 & .06 & $23.32^{\star *}$ \\
\hline \multirow{4}{*}{ Social Risk } & So R 1 & 1.22 & .05 & $23.86^{\star \star}$ \\
\hline & So $\mathrm{R} 2$ & 1.29 & .05 & $24.98^{\star *}$ \\
\hline & So R 3 & 1.17 & .06 & $20.01^{\star \star}$ \\
\hline & So R 4 & 1.26 & .05 & $25.05^{\star \star}$ \\
\hline \multirow{4}{*}{ Physical Risk } & Ph R 1 & 1.31 & .05 & $25.02^{\star \star}$ \\
\hline & Ph R 2 & 1.32 & .05 & $25.91^{\star *}$ \\
\hline & Ph R 3 & 1.30 & .05 & $24.90^{\star *}$ \\
\hline & Ph R 4 & 1.33 & .05 & $26.07^{\star *}$ \\
\hline \multirow{3}{*}{ Psychological Risk } & Ps R 1 & 1.31 & .05 & $24.43^{\star \star}$ \\
\hline & Ps R 2 & 1.34 & .05 & $25.61^{\star \star}$ \\
\hline & Ps R 3 & 1.39 & .05 & $25.13^{\star \star}$ \\
\hline \multirow{4}{*}{ Time Risk } & T R 1 & 1.25 & .05 & $23.60^{\star \star}$ \\
\hline & T R 2 & 1.32 & .05 & $24.23^{\star *}$ \\
\hline & T R 3 & 1.34 & .05 & $25.70^{\star \star}$ \\
\hline & T R 4 & 1.28 & .05 & $24.64^{\star \star}$ \\
\hline
\end{tabular}

Note: ${ }^{\star \star} p<.01 \&{ }^{\star} p<.05$

The observed variables that represent the relationships between the measurement indicators and conducts are statistically significant (see Table 3). The correlations between the primary and secondary dimensions in both groups (Quality, Efficacy, Safety, \& Cost-effectiveness with the BAS, and Functional Risk, Financial Risk, Social Risk,
Physical Risk, Psychological Risk, \& Time Risk with the BIS) were also verified as significant (Table 4).

Table 4. Key statistics

\begin{tabular}{|c|c|c|c|c|c|c|}
\hline $\begin{array}{l}2^{\text {nd }} \\
\text { prder }\end{array}$ & $\begin{array}{l}\text { Latent } \\
\text { Variables }\end{array}$ & $\begin{array}{l}\text { Observed } \\
\text { Variables } \\
\text { of Items }\end{array}$ & Mean & SD & $\begin{array}{l}\text { Confirmator } \\
\text { Factor } \\
\text { Loadings }\end{array}$ & t-value \\
\hline & Quality & $\begin{array}{l}\text { Q } 1 \\
\text { Q } 2 \\
\text { Q } 3\end{array}$ & \begin{tabular}{|l|}
4.63 \\
4.64 \\
4.20
\end{tabular} & $\begin{array}{l}1.41 \\
1.48 \\
1.48\end{array}$ & .96 & $14.79 *$ \\
\hline & Efficacy & $\begin{array}{l}\text { E } 1 \\
\text { E } 2 \\
\text { E } 3 \\
\text { E } 4\end{array}$ & $\begin{array}{l}4.54 \\
4.68 \\
4.79 \\
4.80\end{array}$ & $\begin{array}{l}1.53 \\
1.38 \\
1.41 \\
1.30\end{array}$ & .99 & $18.96^{\star \star}$ \\
\hline $\begin{array}{l}B \\
A \\
S\end{array}$ & Safety & $\begin{array}{l}\text { S } 1 \\
\text { S } 2 \\
\text { S } 3 \\
\text { S } 4\end{array}$ & \begin{tabular}{|l|}
4.81 \\
4.90 \\
4.57 \\
4.75
\end{tabular} & $\begin{array}{l}1.34 \\
1.32 \\
1.35 \\
1.33\end{array}$ & .89 & $18.67^{\star \star}$ \\
\hline & $\begin{array}{c}\text { Cost } \\
\text { Effectiveness }\end{array}$ & $\begin{array}{l}C E 1 \\
C E 2 \\
C E 3 \\
C E 4 \\
C E 5 \\
C E 6\end{array}$ & \begin{tabular}{|l|}
5.13 \\
5.20 \\
4.65 \\
4.97 \\
5.21
\end{tabular} & $\begin{array}{l}1.31 \\
1.30 \\
1.38 \\
1.34 \\
1.36\end{array}$ & .53 & $21.84^{\star \star}$ \\
\hline \multirow{6}{*}{ B I S } & $\begin{array}{l}\text { Functional } \\
\text { Risk }\end{array}$ & $\begin{array}{l}\text { Fu R } 1 \\
\text { Fu R } 2 \\
\text { Fu R } 3 \\
\text { Fu R } 4 \\
\text { Fu R } 5\end{array}$ & $\begin{array}{l}3.04 \\
3.05 \\
3.01 \\
3.05 \\
3.04\end{array}$ & $\begin{array}{l}1.38 \\
1.35 \\
1.29 \\
1.36 \\
1.39\end{array}$ & .87 & $18.62^{\text {*ᄎ }}$ \\
\hline & Financial Risk & $\begin{array}{l}\text { Fi R } 1 \\
\text { Fi R } 2 \\
\text { Fi R } 3\end{array}$ & \begin{tabular}{|l|}
3.05 \\
3.05 \\
3.01
\end{tabular} & $\begin{array}{l}1.38 \\
1.35 \\
1.29\end{array}$ & .95 & $18.21^{\star \star}$ \\
\hline & Social Risk & $\begin{array}{l}\text { So R } 1 \\
\text { So R } 2 \\
\text { So R } 3 \\
\text { So R } 4\end{array}$ & $\begin{array}{l}2.14 \\
2.20 \\
2.43 \\
2.15\end{array}$ & $\begin{array}{l}1.30 \\
1.35 \\
1.39 \\
1.31\end{array}$ & .77 & $16.36^{\star \star}$ \\
\hline & Physical Risk & $\begin{array}{l}\text { Ph R } 1 \\
\text { Ph R } 2 \\
\text { Ph R } 3 \\
\text { Ph R } 4\end{array}$ & $\begin{array}{l}2.70 \\
2.72 \\
2.77 \\
2.72\end{array}$ & $\begin{array}{l}1.37 \\
1.26 \\
1.36 \\
1.36\end{array}$ & .90 & $21.05^{\star \star}$ \\
\hline & $\begin{array}{c}\text { Psychological } \\
\text { Risk }\end{array}$ & $\begin{array}{l}\text { Ps R } 1 \\
\text { Ps R } 2 \\
\text { Ps R } 3\end{array}$ & $\begin{array}{l}2.45 \\
2.40 \\
2.53 \\
\end{array}$ & \begin{tabular}{|l|}
1.38 \\
1.38 \\
1.45 \\
\end{tabular} & .95 & $22.38^{\star \star}$ \\
\hline & Time Risk & $\begin{array}{l}\text { T R } 1 \\
\text { T R } 2 \\
\text { T R } 3 \\
\text { T R } 4\end{array}$ & $\begin{array}{l}2.45 \\
2.55 \\
2.53 \\
2.40\end{array}$ & $\begin{array}{l}1.35 \\
1.40 \\
1.38 \\
1.35\end{array}$ & .95 & $21.84^{\star \star}$ \\
\hline
\end{tabular}

Note: ${ }^{* \star} \mathrm{p}<.01 \&{ }^{\star} \mathrm{p}<.05$ 


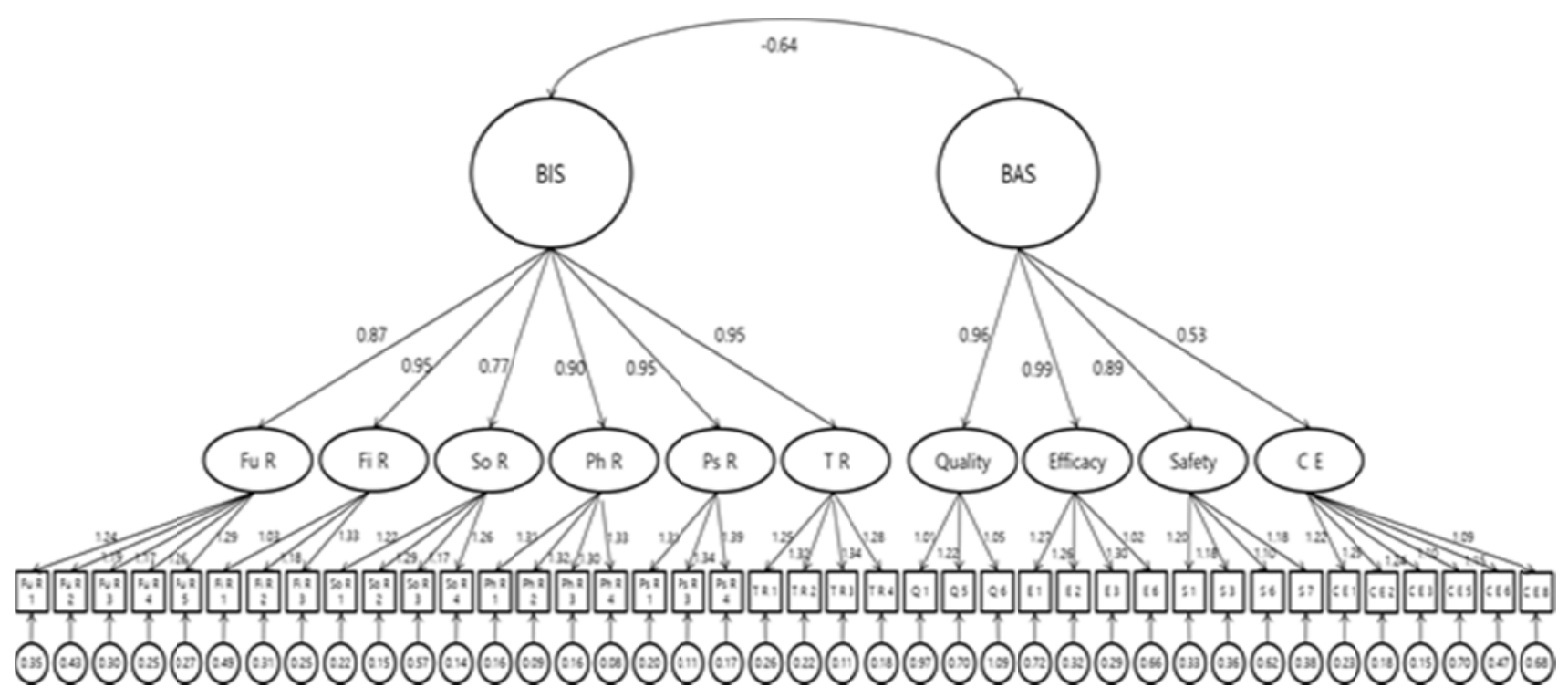

Figure 1. Second order Confirmatory factor analysis of the BIS \& BAS

\subsection{Model Fit}

To evaluate the model for this research, the structuralequation analysis was used. The overall value from the CFA goodness-of-fit test is $\left(\chi_{729}^{2}=2242.97, \mathrm{p}<.01\right)$. Although the $\chi^{2}$ is generally an absolute goodness-of-fit index, it needs to be considered with the other indices to evaluate the adequacy, because the $\chi^{2}$ is directly affected by the sample size. As shown in the results, the model is wellsupported by the $p$-value data $<.01$ with respect to the $\chi^{2}$ statistics. The goodness-of-fit index (GFI) is .75, while the adjusted goodness-of-fit index (AGFI) is .72. These two indices are over .70, thereby satisfying both the acceptance level and the model. The normed fit index (NFI) and the nonnormed fit index (NNFI) are both .98, while the comparative fit index $(\mathrm{CFI})$ is .98. The closer these indices are to 1 , the greater the significance of the results (Kline, 1998). Since each of the present indices is .98 , it is apparent that the model adequacy is very satisfying.

The root mean square error of approximation (RMSEA) is .079 , so the model adequacy fits in a favorable range according to Cudeck and Browne (1993). An RMSEA < .05 is satisfactory. $05 \leq$ RMSEA $<.08$ is an acceptable range, $.08 \leq$ RMSEA $<.10$ is an average level, and an RMSEA $\geq .10$ is outside of the acceptable range. Therefore considering this indices result, the model adequacy of this study is sufficient. The model from the goodness-of-fit test shows that it is classified into two primary dimensional structures. The overall adequacy index from the hierarchical-factor structure fits within the favorable range, thereby allowing the structure to obtain a satisfactory model adequacy of six factors in the BIS and four factors in the BAS (see Table 5).

The description below suggests the structural-equation model of the BIS and BAS scales that pertains to the behavioral systems of Japanese consumers regarding GMs. Peculiarly, however, the correlation coefficient between the BIS and the BAS $(r=-.64)$ and the one between the two factors from Batra and Ahtola (1990) $(r=.55)$ are different. The - .64 value between the BAS and the BIS in [Figure 1] shows that the two primary concepts are contrary to one another and hold completely different implications.

Table 5. Fit indices for the research model

\begin{tabular}{|c|c|c|}
\hline \multicolumn{3}{|c|}{ Fit Index } \\
\hline \multirow{4}{*}{$\begin{array}{l}\text { Absolute Fit } \\
\text { Index }\end{array}$} & & $2242.97(p<.01)$ \\
\hline & Goodness of Fit Index(GFI) & .75 \\
\hline & $\begin{array}{l}\text { Root Mean Square } \\
\text { Residual(RMR) }\end{array}$ & .13 \\
\hline & $\begin{array}{c}\text { Root Mean Square Error of } \\
\text { Approximation(RMSEA) }\end{array}$ & .079 \\
\hline \multirow{4}{*}{$\begin{array}{l}\text { Incremental Fit } \\
\text { Index }\end{array}$} & Non-Normed Fit Index(NNFI) & .98 \\
\hline & Normed Fit Index(NFI) & .98 \\
\hline & $\begin{array}{l}\text { Adjusted Goodness of Fit } \\
\text { Index(AGFI) }\end{array}$ & .72 \\
\hline & Comparative Fit Index(CFI) & .98 \\
\hline
\end{tabular}




\section{Conclusion}

\subsection{Results Summary}

The naming of the term "generic medicine" is based on the "generic name" that is used in the pharmacy prescriptions of Europe and the U.S., and it eliminates the chance of incorrect drug preparations. In Japan, "following drug" and "copied drug" are used for GMs. For the last few decades, European countries have been trying to develop GM markets in which the drugs are relatively less costly and are comparable with the BM version to cut pharmaceutical spending. When a GM is released in the market, it triggers a lowering of the prices of the patent-expired-drugs, thereby saving the consumer costs. Additionally, the research labs in the existing drug companies will focus more on the generation of new medicines rather than on competing with the GM companies. Overall, governments in most countries have been encouraging consumers to take GMs to manage their health-security expenditure, since they have realized that the higher the GM usage, the lower the drug healthcare payout (Shin \& Choi, 2008). Not all consumers, however, share the same positive opinions about GMs despite the expansion of the GM markets. Therefore, by classifying consumer behaviors into the BAS and the BIS, the aim of this study is the suggestion of an alternate plan that can enable consumers to choose the GM option more often.

Many GM studies have been conducted from various perspectives, yet it has not been possible to establish a profound and systematical understanding of the consumer behaviors in terms of the way that their decision-making behaviors are processed. For the present study, the consumer-behavioral-system feature was selected, its model was constructed, and the goodness-of-fit was then evaluated to confirm its adequacy using a second-orderfactor analysis. As a result, a very satisfying model adequacy was found.

A number of important findings have emerged from this study and they are subsequently described. First, to show that the consumer behavioral systems, the BAS and the BIS, are correlated to the consumer behaviors regarding GMs, this work clarified the way that each system plays a role in their distinct behaviors regarding GMs. Also, this work can contribute to the future research since it provides solid theoretical proof in support of the tool developments for the measurement of the BIS and the BAS. Plus, adequate test items were acquired for their use as measurement tools that satisfy both the discrimination and the convenience. Second this work is beneficial to the marketing divisions of pharmaceutical companies that are interested in the specific and various causes of the consumer acceptance and approach toward GMs through its study of the BAS and BIS secondary factors. For instance, they can promptly design the GM ingredients based on the effects of the BIS factors (i.e., risks) and the BAS factors (i.e., quality and efficacy), thereby enabling them to expedite their market share and lead the GM competition when BM patents expire. What needs to be taken into account, however, is that the ingredients are not always influential on the consumer behaviors regarding GMs, but financial support should also be provided for pharmacists to encourage the prescription of GMs (Shirzad, Mohammadi, \& Haghighi, 2015; Simoens \& De Coster, 2006).

Third, this work is also beneficial to governments in terms of the establishment of policies that reduce pharmaceutical expenditures, given the high elderly-population rates and the new pharmaceutical technologies concerning the elderly, as it provides learning on the balancing of the BAS and BIS factors. This means that the policies should be directed toward consumers in consideration of lower-priced GMs that have passed all of the bioequivalence tests and show hardly any efficacy difference compared with the BM versions. To increase the profits from $G M$ sales, a great difference between the BM and GM prices needs to be established. Considering this fact, it is anticipated by the authors of the present study that the greater the domestic BM-GM price difference, the greater the enthusiasm of the government of Japan regarding the pursuance of the use of GMs in its public healthcare systems. Thus, the government must develop actions like public-service announcements to inform consumers about the safety and efficacy of GMs. Lastly, this study has ultimately examined the BAS and BIS factors regarding consumers and GMs, whereby a suitable and adequate research model is presented this is especially relevant for Japan, where a national and social healthinsurance system can carry out surveys to determine the levels of the consumer recognition regarding GMs. Other countries with healthcare systems that are similar to that of Japan could use the same BAS- and BIS-based application methods.

\subsection{Limitations \& Future Study}

The several limitations of this work are as follows. First, the BIS and BAS secondary factors of this study are basically revisions of those of the items from previous marketing research that pertain to general consumers. Although this work has clarified the reliability of these items, additional adequate items that fit the actual respondents' circumstances need to be found. Second, a further understanding of the doctors and pharmacists in Japan needs to be obtained. In 1974, they first introduced separate 
medicine dispensing between doctors and pharmacists, but the implementation rate per region is different, since the government allows a voluntarily following of the guidelines as a result, the total percentage regarding the implementation across the entire country is $57 \%$ (Jeong, 2009).

Mason and Bearden studied whether doctors or pharmacists exert the greater influence on consumers' opinions regarding GMs in Japan (Mason \& Bearden, 1980). They found that the doctors' suggestions were taken more seriously even though the purchasing of GMs would cut their spending. Alternatively, the pharmacists would avoid GM recommendations since they lack any authority over the control of the medicines (Mason \& Bearden, 1980). Hence, the conclusion of this paper is that different consumer surroundings could limit the purchasing of GMs. Third, the previous theories from the conceptual studies (Silpakit \& Fisk, 1985), such as the consumer motives or concerns that occur during the decision-making process, should be proved through further research in terms of the way that the factors directly affect consumer GM purchases. More specifically, the future research should examine the broad surrounding factors including physical and social circumstances and temporary perspectives. Lastly, it would be interesting to study the comparison between those consumers with lesser or greater preferences toward GMs through the conduction of various experiments wherein different environments are manipulated.

For future research, the following points are suggested. First, even though various aged adults participated in this work, the sample could be limited to generalize the results. The consumer attitude toward the BAS and BIS regarding GMs should be confirmed using structures and measurement items in the ongoing future research with a variety of samples. Second, considering the fact that very little research has been conducted on the influence of the BAS and the BIS in terms of the consumer behaviors regarding GMs, more research need to be conducted with various subjects and perspectives for the purpose of an eventual study comparison. Meanwhile, based on the model devised in this study, GM marketers should be able to create ideas that can implore consumers to buy more GM products. Finally, taking into account the high factor-loading values of the Quality (.96), Safety (.89), and Efficacy (.99), this study confirms that consumers could purchase GMs as long as those factors are satisfied. The Japanese Government must therefore actively address the information regarding those three BAS factors to consumers and patients through various policy plans. For instance, they can release the results from the bioequivalence tests to show the quality, safety, and efficacy of GMs to the public. Since the "Bioequivalence Test Guidelines for Following Drugs" paper was released in Japan in 1980, the government has continued developing the qualities of GMs, as well as encouraging the consumption of GMs, and as a result, their spending on pharmaceuticals has stabilized.

The basic directions regarding the establishment of the policy plans for a proper management of the regulations regarding bioequivalent GMs are now presented. First, as a long-term goal, comprehensive policy planning is needed for a smoother supply and promotion of bioequivalent GMs. Second, it is important to help in the removal of the societal doubts regarding bioequivalent GMs including the formation of a consensus through the expansion of seminars and discussions. Third, bioequivalent $\mathrm{GMs}$ need to be distinguished from nonbioequivalent GMs, and actions that further promote bioequivalent GMs need to be implemented.

\section{Discussion}

The further promotion of GM usage should be considered, and this should include the promotion of a stable supply, the ensuring of confidence in GM quality, providing a GM information service, improving the environment for the promotion of GM usage, and monitoring the implementation of the national health insurance from the perspective of each company, industry, and the government.

Firstly, regarding the stable supply, each pharmaceutical company should develop a manual for a stable GM supply and plan for the production capacity and the procurement of active pharmaceutical ingredients in response to the future expansion of the GM market. The Central Government and the pharmaceutical industry associations should prepare guidelines and information in response to the shortages that can occur in oversea countries, and also administrative guidance for national cases where an unstable supply is a risk.

Secondly, to ensure the public confidence in the quality of GMs, each pharmaceutical company should respond promptly to the issues that are identified in the research literature. The Central Government should monitor the scientific literature, the Review Committee on Quality of Generics, and the quality of the GMs on the market. Further, local governments should conduct educational activities for consumers to facilitate a better overall understanding regarding the quality of GMs.

Thirdly, regarding the information service, each company should improve their information collection and provision process, and industrial associations should expand their existing GM information service. Local governments should use community-level councils for the promotion of GMs and 
prepare lists of the widely used GMs in each community. Fourth, regarding environmental improvements for the promotion of GM usage, the central and local governments should act in agreement with the National Health Care Cost Containment Plan. Private insurance companies (healthinsurance associations) should expand their notifications to patients concerning the price differences between GMs and BMs. Lastly, regarding the status of the national health insurance and the monitoring of the implementation status, the Central Government should consider the recommendations of the Central Social Insurance Medical Council and other relevant bodies, and it should also conduct monitoring on the implementation-status approaches and the results evaluation.

\section{References}

Anderson, J. C., \& Gerbing, D. W. (1988). Structural equation modeling in practice: A review and recommended two-step approach. Psychological Bulletin, 103(3), 411-423.

https://doi.org/10.1037/0033-2909.103.3.411

Bae, S. J., Lim, J. H., \& Bae, E. Y. (2009). The review of pharmaceutical pricing policy $\square$ : Focused on reevaluation of other countries. Seoul: Health Insurance Review \& Assessment Service, 2017.

Bearden, W. O., \& Mason, J. B. (1978). Consumerperceived risk and attitudes toward generically prescribed drugs. Journal of Applied Psychology, 63(6), 741-746. https://doi.org/10.1037/0021-9010.63.6.741

Bettman, J. R. (1975). Information Integration in consumer risk perception: A comparison of two models of component conceptualization. Journal of Applied Psychology, 60(3), 381-385. https://doi.org/10.1037/h0076623

Blattberg, R. C., \& Wisniewski, K. J. (1989). Price-induced patterns of competition. Marketing Science, 8(4), 291-309. https://doi.org/10.1287/mksc.8.4.291

Bollen, K. A. (1989). A New Incremental Fit Index for General Structural Equation Models. Sociological Methods \& Research, 17(3), 303-316. https://doi.org/10.1177/0049124189017003004

Brekke, K. R., Holmås, T. H., \& Straume, O. R. (2010). Margins and market shares: Pharmacy incentives for generic substitution. European Economic Review, 61(July), 116-131.

https://doi.org/10.1016/j.euroecorev.2013.02.005
Brooker, G. (1984). An assessment of an expanded measure of perceived risk. Advances in Consumer Research, 11, 439-411.

Browne, M. W., \& Cudeck, R. (1993). Alternative ways of assessing model fit. In K. A. Bollen \& J. S. Long (Eds.), Testing structural equation models (pp. 136162). Newbury Park, CA: Sage.

Carver, C. S., \& White, T. L. (1994). Behavioral inhibition, behavioral activation, and affective responses to impending reward and punishment: The BIS/BAS Scales. Journal of Personality and Social Psychology, 67(2), 319-333.

https://doi.org/10.1037/0022-3514.67.2.319

Chandon, P., Wansink, B., \& Laurent, G. (2000). A benefit congruency framework of sales promotion. Journal of Marketing, 64(4), 65-81.

Choi, Y. J., \& Choi, S. E. (2009). The review of pharmaceutical reimbursement policy. Seoul: Health Insurance Review \& Assessment Service.

Chong, C. P., March, G., Clark, A., Gilbert, A., Hassali, M. A., \& Bahari, M. B. (2011). A nationwide study on generic medicines substitution practices of Australian community pharmacists and patient acceptance. Health Policy, 99(2), 139-148. https://doi.org/10.1016/j.healthpol.2010.08.002

Churchill, G. A. (1979). A paradigm for developing better measures of marketing constructs. Journal of Marketing Research, 16(1), 64. https://doi.org/10.2307/3150876

Clow, K. E., Kurtz, D. L. D., Ozment, J., \& Ong, B. S. (1997). The antecedents of consumer expectations of services: An empirical study across four industries. Journal of Services Marketing, 11(4), 230-248. https://doi.org/10.1108/08876049710171704

Davidson, R. J. (1993). Parsing affective space: Perspectives from neuropsychology and psychophysiology. Neuropsychology, 7(4), 464-175. https://doi.org/10.1037/0894-4105.7.4.464

Depue, R. A., Krauss, S. P., \& Spoont, M. R. (1987). A twodimensional threshold model of seasonal bipolar affective disorder. In D. Magnusson \& A. Ohman (Eds.), Personality, psychopathology, and Psychotherapy. Psychopathology: An interactional perspective (pp. 95-123). San Diego: Academic Press. Retrieved from http://publicaciones.umh.es/ docview $/ 617360305$ ?accountid=28939

Depue, R. A., \& lacono, W. G. (1989). Neurobehavioral aspects of affective disorders. Annual Review of Psychology, 40, 457-92. 
Dylst, P., Vulto, A., \& Simoens, S. (2012). Overcoming challenges in market access of generic medicines in the European Union. Journal of Generic Medicines: The Business Journal for the Generic Medicines Sector, 9(1), 21-28. https://doi.org/10.1177/1741134312441107

Erdle, S., \& Rushton, J. P. (2010). The general factor of personality, BIS-BAS, expectancies of reward and punishment, self-esteem, and positive and negative affect. Personality and Individual Differences, 48(6), 762-766. https://doi.org/10.1016/j.paid.2010.01.025

FDA Fact Sheet: What's Involved in Reviewing and Approving Generic Drug Applications?. (2017). Retrieved from https://www.fda.gov/drugs/resources foryou/consumers/buyingusingmedicinesafely/generi cdrugs/ucm506040.htm

Gable, S. L., Reis, H. T., \& Elliot, A. J. (2000). Behavioral activation and inhibition in everyday life. Journal of Personality and Social Psychology, 78(6), 11351149. https://doi.org/10.1037//0022-3514.78.6.1135

Ganther-Urmie, J. M., Nair, K. V., Valuck, R., McCollum, M., Lewis, S. J., \& Turpin, R. S. (2004). Consumer attitudes and factors related to prescription switching decisions in multitier copayment drug benefit plans. American Journal of Managed Care, 10(3), 201-208.

Ghassemzadeh, H., Hojabri, R., Eftekhar, F., \& Moslem, S. (2013). Tacit Knowledge sharing in health industry: Influences of, personal, organizational and social factors. The East Asian Journal of Business Management, 3(1), 29-35.

Gonzalez, J., Sismeiro, C., Dutta, S., \& Stern, P. (2008). Can branded drugs benefit from generic entry? The role of detailing and price in switching to nonbioequivalent molecules. International Journal of Research in Marketing, 25(4), 247-260. https://doi.org/10.1016/j.jresmar.2008.08.002

Gray, J. A. (1976). The behavioral inhibition system: A possible substrate for anxiety. In M. P. Feldman \& A. M. Broadhurst (Eds.), Theoretical and Experimental Bases of the Behaviour Therapies (pp.3-41). London: Wiley.

Gray, J. A. (1981). A critique of Eysenck's theory of personality. In H. J. Eysenck (Ed.), A Critique of Eysenck's Theory of Personality (pp. 246-276). Berlin, Heidelberg: Springer. https://doi.org/10.1007/978-3-642-67783-0_8

Ikegami, N., Yoo, B. K., Hashimoto, H., Matsumoto, M., Ogata, H., Babazono, A., Kobayashi, Y. (2011). Japanese universal health coverage: Evolution, achievements, and challenges. The Lancet, 378(9796), 1106-1115.

https://doi.org/10.1016/S0140-6736(11)60828-3

Ishii, S., Ogawa, S., \& Akishita, M. (2015). The state of health in older adults in Japan: Trends in disability, chronic medical conditions and mortality. PLOS ONE, 10(10), 1-13.

https://doi.org/10.1371/journal.pone.0139639

Jacoby, J., \& Kaplan, L. B. (1972). The components of perceived risk. In M. Venkatesan (Ed.), SV Proceedings of the Third Annual Conference of the Association for Consumer Research (pp.382-393). Chicago, IL: Association for Consumer Research. Retrieved from http://acrwebsite.org/volumes/12016/ volumes/sv02/SV-02

Jakovljevic, M. B., Nakazono, S., \& Ogura, S. (2014). Contemporary generic market in Japan - Key conditions to successful evolution. Expert Review of Pharmacoeconomics and Outcomes Research, 14(2), 181-194. https://doi.org/10.1586/14737167.2014.881254

Jeong, H. S. (2009). Pharmaceutical reforms: Implications through comparisons of Korea and Japan. Health Policy, 93(2-3), 165-171.

https://doi.org/10.1016/j.healthpol.2009.07.009

Kaiser, H. F. (1960). The Application of electronic computers to factor analysis. Educational and Psychological Measurement, 20(1), 141-151. https://doi.org/10.1177/001316446002000116

Kassarjian, H. H., \& Robertson, T. S. (1991). Perspectives in Consumer Behavior (4th ed.). Englewood Cliffs, N.J.: Prentice Hall.

Kim, D. (2018). The effects of city brand image on city brand recognition and city loyalty. International Journal of Industrial Distribution \& Business, 9(3), 69-79.

Kim, D. H, Cha, J. B, \& Park, C. W. (2017). The effect of customer orientation on perceived referral risk and referral intention. Journal of Distribution Science, 15(7), 61-71. https://doi.org/10.15722/jds.15.7.201707.61

Kim, E. H., Kim, E. H., \& Kim, M. J. (2011). The effect of distributor private brand product type on consumer attitude. The East Asian Journal of Business Management, 1(1), 13-20.

Kim, G. B., \& Kim, B. G. (2017). Causality of consumerbrand relationship variables in global brand and the effects of moderating variables. Journal of Distribution Science, 15(2), 121-132. https://doi.org/10.15722/jds.15.2.201702.121 
Kim, M., \& Kim, E. (2017). Differences in perceived risk and product attitudes $\square$ : Focus on Korea and Thailand consumers. International Journal of Industrial Distribution \& Business, 8(6), 41-49.

Kim, S. (2013). A study on the impact of oil price volatility on Korean macro economic Activities: An EGARCH and VECM approach. Journal of Distribution Science, 11(10), 73-79. https://doi.org/10.13106/jds.2013.vol11.no10.73.A

Kline, R. B. (1998). Software Review: Software programs for structural equation modeling: Amos, EQS, and LISREL. Journal of Psychoeducational Assessment, 16(4), 343-364. https://doi.org/10.1177/073428299801600407

Kuribayashi, R., Matsuhama, M., \& Mikami, K. (2015). Regulation of generic drugs in Japan: The current situation and future prospects. The AAPS Journal, 17(5), 1312-1316. https://doi.org/10.1208/s12248-015-9777-x

Lambert, Z. V., Doering, P. L., Goldstein, E., \& McCmormick, W. C. (1980). Predispositions toward generic drug acceptance. Journal of Consumer Research, 7(1), 14-23.

Mason, J. B., \& Bearden, W. O. (1980). Generic drugs: Consumer, pharmacist and physician perceptions of the issues. Journal of Consumer Affairs, 14(1), 193206.

MHLW. (2012). Promotion of the Use of Generic Drugs. Retrieved from http://www.mhlw.go.jp/english/policy_ report/2012/09/120921.html

Mieres, C. G., Martín, A. M. D., \& Gutiérrez, J. A. T. (2006). Antecedents of the difference in perceived risk between store brands and national brands. European Journal of Marketing, 40(1/2), 61-82. https://doi.org/10.1108/03090560610637310

Narasimhan, C. (1984). A price discrimination theory of coupons. Marketing Science, 3(2), 128-147.

OECD. (2017). Elderly population (indicator). https://doi.org/10.1787/8d805ea1-en

OECD. (2017). Generics and biosimilars. In Health at a Glance 2017: OECD Indicators. Paris: OECD Publishing. http://doi.org /10.1787/health_glance-2017-71-en

OECD. (2017). Tackling Wasteful Spending on Health. Paris. https://doi.org/10.1787/9789264266414-en

OECD Health Statistics 2016 Definitions, Sources and Methods. (2016). https://doi.org/10.2478/v10039-012-0075-x

Olson, J. C., \& Jacoby, J. (1972). Cue utilization in the quality perception process. In Proceedings of the
Third Annual Conference of the of the Association for Consumer Research (pp.167-179).

https://doi.org/10.1108/eb026082

Peter, J. P., \& Ryan, M. J. (1976). An investigation of perceived risk at the brand level. Journal of Marketing Research, 13(2), 184-188. https://doi.org/10.2307/3150856

Peter, J. P., \& Tarpey, L. X. (1975). A comparative analysis of three consumer decision strategies. Journal of Consumer Research, 2(June), 215-224. http://dx.doi.org/10.1086/208613

Podulka, M., Krautkramer, K., Amerson, D., Phillips, B., \& Dolinsky, D. (1989). Consumers' attitudes toward generic drugs. Journal of Pharmaceutical Marketing \& Management, 4(1), 93-104. https://doi.org/10.3109/J058v04n01_06

Prashar, S., Raja, A., Parasaran, V. S., \& Venna, V. K. (2015). Factors prompting impulse buying behavior: Shoppers in Dubai. East Asian Journal of Business Management, 5(3), 5-15. https://doi.org/10.13106/eajbm.2014.vol5.no3.5.

Quay, H. C. (1988). The behavioral reward and inhibition system in childhood behavior disorder. In L. M. Bloomingdale (Ed.), Attention deficit disorder, Vol. 3. New Research in Attention, Treatment, and Psychopharmacology (pp.176-186). Elmsford: Pergamon Press.

Quay, H. C. (1993). The psychobiology of under-socialized aggressive conduct disorder: A theoretical perspective. Development and Psychopathology, 5(1-2), 165-180. https://doi.org/10.1017/S0954579400004326

Richardson, P. S., Dick, A. S., \& Jain, A. K. (1994). Extrinsic and intrinsic cue effects on perceptions of store brand quality. Journal of Marketing, 58(4), 28-36. https://doi.org/10.2307/1251914

Rizzo, J. A., \& Zeckhauser, R. (2009). Generic script share and the price of brand-name drugs: The role of consumer choice. International Journal of Health Care Finance and Economics, 9(3), 291-316. https://doi.org/10.1007/s10754-008-9052-0

Schiffman, L. G., \& Kanuk, L. L. (1994). Consumer Behavior (5th ed.). Upper Saddle River, NJ: Prentice Hall. https://doi.org/10.1002/cb.84

Shepherd, M. D. (1988). Consumer drug purchases are based on perceptions of quality, survey on generics finds. Am J Hosp Pharm, 45, 1245.

Shin, J. Y., \& Choi, S. E. (2008). The volume and the price of generic drug consumption in Korea Prescription 
Drug Market. The Korean Journal of Health Economics and Policy, 14(1), 103-125.

Shirzad, A., Mohammadi, S., \& Haghighi, R. (2015). Effect of financial performance on earnings management in the drug distribution industry. International Journal of Industrial Distribution \& Business, 6(4), 23-26.

Shrank, W. H., Cox, E. R., Fischer, M. A., Mehta, J., \& Choudhry, N. K. (2009). Patients' perceptions of generic medications. Health Affairs, 28(2), 546-556. https://doi.org/10.1377/hlthaff.28.2.546

Shrank, W. H., Hoang, T., Ettner, S. L., Glassman, P. A., Nair, K., DeLapp, D., ․ Asch, S. M. (2006). The implications of choice. Archives of Internal Medicine, 166(3), 332-337. https://doi.org/10.1001/archinte.166.3.332

Silpakit, P., \& Fisk, R. P. (1985). Services marketing in a changing environment. In T. M. Bloch, G. D. Upah, \& V. A. Zeithaml (Eds.), Services Marketing in a Changing Environment (pp. 117-121). Chicago, IL: American Marketing Association.

Simoens, S., \& De Coster, S. (2006). Sustaining generic medicines markets in Europe. Journal of Generic Medicines, 3(4), 257-268. https://doi.org/10.1057/palgrave.jgm.4940128

Stone, R. N., \& Grønhaug, K. (1993). Perceived Risk: Further considerations for the marketing discipline. European Journal of Marketing, 27(3), 39-50. https://doi.org/10.1108/03090569310026637

Stone, R. N., \& Winter, F. W. (1987). Risk: Is it still uncertainty times consequences. In In Proceedings of the American Marketing Association (Vol. 1, pp. 261-265). Chicago, IL.

Sweeny, J. C., \& Soutar, G. N. (2001). Consumer perceived value: The development of a multiple item scale. Journal of Retailing, 77(2), 203-220. https://doi.org/10.1016/j.jretai.2006.1

The Aging Society: Current Situation and Implementation Measures. (2015). Tokyo. Retrieved from http://www8.cao.go.jp/kourei/english/annualreport/20 15/2015pdf_e.html

Tootelian, D. H., Gaedeke, R. M., \& Schlacter, J. (1988). Branded versus generic prescription drugs: Perceptions of risk, efficacy, safety, and value. Journal of Health Care Marketing, 8(3), 26-9. Retrieved from http://www.ncbi.nlm.nih.gov/pubmed /10289937

Vincent, M., \& Zikmund, W. G. (1976). An experimental investigation of situational effects on risk perception. Advances in Consumer Research, 3, 125-129. Retrieved from http://acrwebsite.org/volumes/9185/ volumes/v03/NA-03

Yach, D., Hawkes, C., Gould, C. L., \& Hofman, K. J. (2004). The global burden of chronic diseases: overcoming impediments to prevention and control. Jama, 291(21), 2616-22. https://doi.org/10.1001/jama.291.21.2616

Zikmund, W. G., \& Scott, J. E. (1977). An investigation of the role of product characteristics in risk perception. Review Of Business and Economic Research, 13(1), 19. 